\title{
INVESTIGATION OF THE ANNUAL VARIABILITY OF THE ALEPPO PINE TREE-RINGS WIDTH: THE RELATIONSHIPS WITH THE CLIMATIC CONDITIONS IN THE ATTICA BASIN
}

\author{
A. PAPADOPOULOS ${ }^{1, *}$ \\ K. TOLIKA ${ }^{2}$ \\ A. PANTERA ${ }^{1}$ \\ P. MAHERAS ${ }^{2}$
}

\author{
${ }^{1}$ T.E.I. Lamias, Forestry Department \\ and Natural Environment Management \\ 36100 Karpenissi, Greece \\ ${ }^{2}$ Department of Meteorology and Climatology \\ School of Geology, Aristotle University of Thessaloniki \\ Thessaloniki, 54124, Greece
}

Received: 05/02/07

Accepted: 23/05/07 *to whom all correspondence should be addressed: e-mail: ampapadopoulos@teilam.gr

\section{ABSTRACT}

The relationships between the annual variability of the Aleppo pine tree-ring widths and the variability of the main climatic parameters in the Attica basin are analysed in the present study for a 45-year period (1959-2003). The Principal Components Analysis was applied to the times-series of the tree-rings indices (12 populations) as well as to the residual timeseries of the monthly precipitation, maximum and minimum temperatures derived from 5 meteorological stations located in the study region. The results showed that the $64 \%$ of the total variance of the tree-rings of the Aleppo pine could be attributed to the common variability of the climatic parameters: for precipitation with $82.6 \%$, for minimum temperature with $88.2 \%$ and for maximum temperature with $88.5 \%$ of the total variance of each parameter. Characteristic narrow and wide tree-rings were observed during the hydrological years with extreme rainfall or temperature conditions. Finally the study of the climate growth links, on a local basis, showed that the growth of the Aleppo pine is related positively (positive correlations) with the winter and spring precipitations. On the other hand negative correlations were found with the temperatures of the spring months.

KEYWORDS: dendroclimatology, climatology, Aleppo pine, basin of Attica.

\section{INTRODUCTION}

Climate is one of the most important factors that influence, among others factors (physiographic, edaphic, biotic) the vegetation growth and distribution (Quezel, 1974; Critchfield, 1983; Kutiel et al., 2000). The most distinctive effect of the climate to the tree growth is the one observed to the width of the annual tree rings. According to Fritts (1976), the tree-ring width is the final result of the interaction of complex internal and environmental factors among which the climate plays a prevailing role. The examination and the analysis of the effects of the climatic factors to the width growth of the trees, is the main field of interest of dendroclimatology, which is a sub-branch of dendroecology, the science of dendrochronology (Fritts, 1976; Schweingruber, 1988; 1996; Kaennel and Schweingruber, 1995).

Aleppo pine is the main tree species in the Attica Basin. Its presence all over the basin as well as the presence of stands and old trees renders it an ideal species for the identification and the analysis of the climate to annual tree rings relationship in the study area. Aleppo pine, a species of high adaptive capacity in different Mediterranean climatic - edaphic environments (Barbero et al., 1998), has been the subject of several dendroecological a dendroclimatological studies in many Mediterranean regions (Lev- Yadun et al., 1981; SerreBachet, 1985; 1992; Mokrim, 1989; Safer, 1994; Nicault, 1999; Touchan and Hughes, 1999; 
Rathgeber et al., 2003) including Greece (Papadopoulos, 1993; Papadopoulos et al., 2001; 2006). From the aforementioned studies it appears that the climatic conditions play an important role in the annual tree-rings width variability and visual characteristics (narrow or wide rings, discolored rings, wide latewood).

It should also be mentioned that there have been several studies on the analysis of the variability of the main meteorological parameters and of the climate in general of the study area (Athens), (Katsoulis and Kambetzidis, 1989; Bartzokas and Metaxas, 1995; Philandras et al., 1999; Founda et al., 2004). In most of them, rainfall and temperature variability is interpreted by examining the relationships of these parameters with the general circulation of the atmosphere and other geographical or local factors. However, the Attica basin has not been examined systematically from the dendroclimatological point of view. The only exception is the study of Margiolopoulos (1962), which analysed the 35-year circles of the rainy periods of Bruckner, during the ancient times, in comparison with successive tree - ring series found on pieces of cypress wood (Cupressus sempervirens) at the archeological area of the Parthenon.

The objective of the present study is the analysis and the connection over time and space of the variability of the Aleppo pine tree- rings width and the variability of the main climatological factors (precipitation, maximum and minimum temperature) at the Attica Basin for the last 45 years. The study also aims at the identification of the relationships between the tree-ring width and the climatological conditions as well as at the correlation of the extreme events with the presents of characteristic narrow or wide tree-rings. Finally, a first attempt is made to investigate, on a local scale, the relations of the ring growth and climate.

\section{DATA AND METHODS}

\subsection{Dendrochronological data and methods}

The dendrochronological data employed in this study, were derived from the analysis and the measurement of the annual tree-ring widths from 12 different locations of urban and suburban Aleppo pine forests or stands over the Attica basin. From hereafter they will be mentioned as Aleppo pine populations (Figure 1). In each region, and based on dendrochronological criteria (Fritts, 1976; Schweingruber, 1988) two core samples were extracted with an increment borer at breast height $(1.3 \mathrm{~m})$ from opposite sides of each tree, and in total 10-37 cores per region.

The cores were prepared in a way that the treerings would be as distinct as possible and they were dated using the cross dating method following the classical processes (Fritts, 1976; Schweingruber, 1996). Afterwards the widths of the tree-rings were measured with an approximation of $0.01 \mathrm{~mm}$ using the WinDendro system (Régant, 2001), and were subsequently transformed into indices. From the chronology indices of each population, a mean time-series

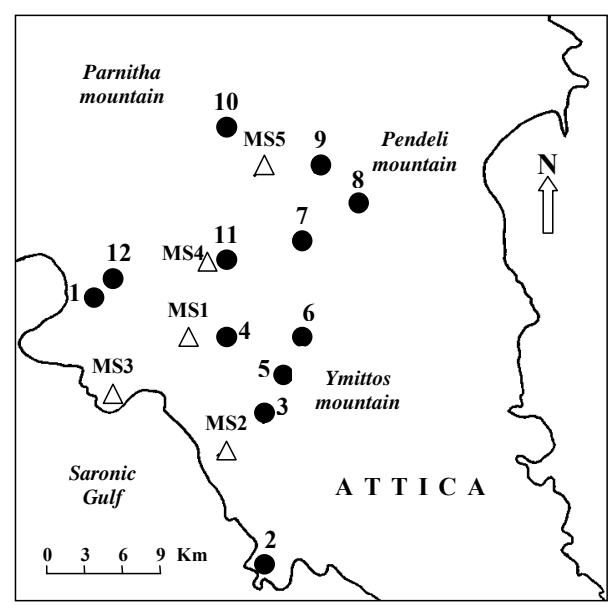

Figure 1. Locations of tree-ring sites: 1. Diomedes Botanical Garden, 2. Kavouri, 3. Ilioupoli, 4. Lykavittos, 5. M. Kessarianis, 6. Ymittos, 7. Ktima Sygrou, 8. N. Penteli, 9. N. Erythrea, 10.Tatoi, 11. N. Philadelphia, 12. Pikilo Oros, and Meteorological Stations: MS1. National Observatory of Athens, MS2. Elliniko, MS3. Piraeus, MS4. N. Philadelphia, and MS5 Tatoi of indices was constructed. The transformation of the original data to indices was firstly done by applying a high-pass filter with a 20 -year window, in order to eliminate low frequency trends. Secondly, an index was calculated by dividing the actual tree-ring width by the curve-fit value (Guiot, 1990). This process is necessary a) for the elimination of the tree-ring width decrease due to tree aging and b) in order to reinforce the climate signal in the tree-rings (Fritts, 1976; Cook et al., 1989). Table 1 summarizes the geographical characteristics of the populations as well as the equivalent characteristics of the annual tree-ring time- series. 
Table 1. Geographical coordinates of the Aleppo pine populations and characteristics of the tree-rings time series

\begin{tabular}{|c|c|c|c|c|c|c|}
\hline$\alpha / \alpha$ & $\begin{array}{l}\text { Aleppo pine } \\
\text { populations }\end{array}$ & Latitude & Longitude & $\begin{array}{c}\text { Altitude } \\
\text { (m) }\end{array}$ & $\begin{array}{c}\text { Number of } \\
\text { trees/(cores) }\end{array}$ & $\begin{array}{l}\text { Total period } \\
\text { of mean } \\
\text { chronologies }\end{array}$ \\
\hline 1 & $\begin{array}{l}\text { Diomedes } \\
\text { Botanical } \\
\text { Garden }\end{array}$ & $38^{\circ} 00^{\prime}$ & $23^{\circ} 37^{\prime}$ & 180 & $23(37)$ & 1843-2003 \\
\hline 2 & Kavouri & $37^{\circ} 49^{\prime}$ & $23^{\circ} 46^{\prime}$ & 10 & $8(15)$ & 1886-2003 \\
\hline 3 & Ilioupoli & $37^{\circ} 55^{\prime}$ & $23^{\circ} 45^{\prime}$ & 240 & $10(15)$ & $1916-2003$ \\
\hline 4 & Lykavittos & $37^{\circ} 59^{\prime}$ & $23^{\circ} 44^{\prime}$ & 210 & $12(21)$ & $1930-2003$ \\
\hline 5 & $\begin{array}{l}\text { Moni } \\
\text { Kessarianis }\end{array}$ & $37^{\circ} 58^{\prime}$ & $23^{\circ} 46^{\prime}$ & 190 & $10(15)$ & $1951-2003$ \\
\hline 6 & Ymittos & $37^{\circ} 58^{\prime}$ & $23^{\circ} 49^{\prime}$ & 530 & $7(12)$ & $1957-2003$ \\
\hline 7 & Ktima Sygrou & $38^{\circ} 03^{\prime}$ & $23^{\circ} 49^{\prime}$ & 260 & $10(17)$ & $1863-2003$ \\
\hline 8 & Nea Penteli & $38^{\circ} 04^{\prime}$ & $23^{\circ} 52^{\prime}$ & 490 & $11(16)$ & $1911-2003$ \\
\hline 9 & Nea Erythrea & $38^{\circ} 06^{\prime}$ & $23^{\circ} 50^{\prime}$ & 270 & $10(20)$ & $1945-2003$ \\
\hline 10 & Tatoi & $38^{\circ} 08^{\prime}$ & $23^{\circ} 46^{\prime}$ & 520 & $10(18)$ & $1897-2003$ \\
\hline 11 & N. Philadelphia & $38^{\circ} 03^{\prime}$ & $23^{\circ} 44^{\prime}$ & 130 & $11(22)$ & $1957-2003$ \\
\hline 12 & Pikilo Oros & $38^{\circ} 01^{\prime}$ & $23^{\circ} 38^{\prime}$ & 360 & $6(10)$ & $1950-2003$ \\
\hline
\end{tabular}

Using the software GALCPC (Guiot, 1992), the Principal Component Analysis (PCA) based on the correlation matrix and the criterion PVP, was employed to the data of the 12 mean time-series of the tree-ring indices, for the common period 1959-2003. The matrix used had a dimension of $12 \times 45$, where 12 are the variables and 45 are the observations. The PCA was applied for the grouping of the Aleppo pine populations of similar growth pattern as well as for the determination of possible differences in the chronologies caused by the local climate characteristics of the stations. For each of the principal components that account the greatest percentage of the total variability, a set of the principal loadings and scores was calculated and analysed.

\subsection{Climatological Data and Methods}

The data used in the study are monthly precipitation, maximum and minimum temperature time-series, derived from 5 meteorological stations over the Attica basin, covering the time period of hydrological years from 1958-59 to 2002-03. The geographical characteristics and the number of observations of each station are presented in Table 2.

Table 2. Geographical characteristics of the stations under study and the number of observations for the selected meteorological parameters

\begin{tabular}{lllrrrr}
\hline $\begin{array}{l}\text { Meteorological } \\
\text { Stations }\end{array}$ & Latitude & Longitude & \multicolumn{2}{c}{$\begin{array}{c}\text { Altit. } \\
(\mathbf{m})\end{array}$} & & \multicolumn{3}{c}{ Number of Observations } \\
\cline { 5 - 7 } & & & $\mathbf{P}$ & Tmin & Tmax \\
\hline $\begin{array}{l}\text { 1 National Observ. } \\
\text { of Athens }\end{array}$ & $37^{\circ} 58^{\prime}$ & $23^{\circ} 43^{\prime}$ & 107 & 528 & 540 & 540 \\
2 Elliniko & & & & & & \\
3 N. Philadelphia & $37^{\circ} 54^{\prime}$ & $23^{\circ} 45^{\prime}$ & 15 & 540 & 540 & 540 \\
4 Piraeus & $38^{\circ} 03^{\prime}$ & $23^{\circ} 40^{\prime}$ & 138 & 523 & 528 & 528 \\
5 Tatoi & $37^{\circ} 56^{\prime}$ & $23^{\circ} 38^{\prime}$ & 5 & 534 & 535 & 535 \\
& $38^{\circ} 06^{\prime}$ & $23^{\circ} 47^{\prime}$ & 235 & 519 & 538 & 538 \\
\hline
\end{tabular}

All these data were provided from the National Meteorological Service and the National Observatory of Athens. The monthly data were preferred since they are most commonly used in dendroclimatological applications and studies, in order to estimate and analyze the relationships between the climate and the growth of the tree-rings (Fritts, 1976). Also, the data series were checked for homogeneity with the aid of the Alexandersson (1986) homogeneity test for each station separately. The station of NOA (National Observatory of Athens) was selected as the reference time series, since it satisfies all the necessary criteria 
(i.e. no changes of instruments and observing practices). According to the results of the test the data of all the stations were found to be homogeneous.

Rainfall and temperature are two of the main meteorological factors that influence the climate in the study area (Bartzokas and Metaxas, 1995). Also, they have a great biological value for the analysis of the relations between the climate and the examined tree-rings growth (Fritts 1976; Schweingruber, 1988). The hydrological year was defined as a period of 12 months, from the October of the previous year to the September of the next year. This period is the most widely used for dendroclimatological and dendrocroecological purposes in the Mediterranean region (Berger et al., 1979; Serre-Bachet, 1985; Schweingruber, 1988; Garfi, 2000).

A small number of missing values found in some of the time-series were completed using a statistical process which is essential for the analysis of the variability of the climatic parameters (Guiot, 1986) and which is based on multiple regressions. The software used was CALMRG (Guiot, 1990). The regression was applied separately to each of the three data matrices (dim. 5x 540), where 5 is the number of stations and 540 is the number of the monthly observations for precipitation maximum and minimum temperature respectively, for the hydrological years from 1958-59 to 2002-03. The estimation of the validity of the computation of the missing values is significant at a level of $99.9 \%$. The estimation error is very small and concerns only a very small number of observations $(0.012-0.039 \%)$ which does not influence the quality of the used data.

Moreover, in order to eliminate the influence of the seasonality of the data to the correlation of the variables, the observations were transformed into residual values, by computing the deviations of the monthly values from the monthly average of all the hydrological years. Principal component analysis was applied to the new matrices of these residual values, for each climatic parameter separately, with the same method that was employed to the treering data (Guiot, 1990). This is a widely used method for the study of the annual variability of the Mediterranean climate (Maheras, 1981; Guiot, 1986; Papadopoulos, 1994; Xoplaki et al., 1998; Maheras et al., 1999).

Finally, a primer trend analysis of the monthly temperature and precipitation data by applying the Mann - Kendal test, showed that both the maximum and the minimum temperatures presented a decreasing trend (not statistically significant) generally from the end of the $70^{\prime}$ until the beginning of the 90'. Afterwards the temperature data presented an increasing trend (more intense in the case of the maximum values), which lasts until the end of the examined period. This positive trend is statistically significant (at a level of 0.05 ) mainly for the summer maximum temperatures. Concerning precipitation, it could be mentioned that the winter and autumn rainfall totals of all the stations presented a negative trend (decrease) approximately from the end of the 80 ' until 2003. Due to space limitations the aforementioned results are not shown in the present paper.

\subsection{Relationships between the climatic data and the tree-ring widths.}

The tree-ring data were correlated separately with each one of the climatic parameters for each month. This correlation was made between the first principal component (PC1) scores, of the tree-rings and the PC1 scores of precipitation, maximum and minimum temperature, for each month of the defined hydrological years. The use of the PCA scores aims at defining the existing relationship between the tree-ring growth of the 12 Aleppo pine populations and the local climate described by the selected parameters (Prec, Tmax, Tmin) from the 5 stations under study. On a final step of the study, the years with characteristically narrow or wide tree-rings were analyzed in comparison to the scores profile of the precipitation, Tmax and Tmin of the equivalent years that these rings had been observed. 


\section{RESULTS}

\subsection{Dendrochronological Analysis}

After the application of the unrotated Principal Component Analysis (PCA) to the 12 main time-series of the annual tree-ring indices, it was found that the first PC (PC1) was associated with the highest percentage of the total variance $(64 \%)$ and it was further analyzed. The other PCs account much smaller percentages of the total variance, representing particular minor factors that may influence the tree growth, which are difficult to be interpreted and explained (Table 3).

Table 3. Principal components derived from 12 tree-ring chronologies

\begin{tabular}{ccc}
\hline $\begin{array}{c}\text { Principal } \\
\text { component }\end{array}$ & \% total variance & $\begin{array}{c}\text { Cumulative \% } \\
\text { variance explained }\end{array}$ \\
\hline PC1 & 64,0 & 64,0 \\
PC2 & 7,7 & 71,7 \\
PC3 & 6,2 & 77,9 \\
PC4 & 4,6 & 82,5 \\
\hline
\end{tabular}

More specifically, the first principal component represents the common tree-rings width variability, for the total number of the time-series. The weighting coefficients (component loadings) for the first principal component provide useful information about similarities among the chronologies of Aleppo pine populations (not shown). This variance could be attributed to the influence of all climatic parameters to the tree growth of the 12 populations of the Aleppo pine in the Attica basin. This climatic effect is additionally evidenced by the high mean sensitivity values of the tree-ring width time-series of the area (Papadopoulos et al., 2006). From a previous study on the same tree species over the continental Greece, the percentage of this common variance reached the value of $42 \%$ (Papadopoulos, 1994). The correlation coefficients among the populations are quite high and vary from 0.44 to 0.79 . Conversely, the station correlation is random and does not seem to depend on geographical or other station factors that characterize or influence the tree populations.

Figure 2 depicts the PC1 score values during the time period 1959-2003. The negative scores represent the years with narrow tree rings and the positive scores the wide ones. The most characteristic tree-rings were found at the following years:

a) Narrow tree-rings: 2000, 1990, 2001, 1993, 1968, 1986, 1977 and 1975,

b) Wide tree-rings: 1972, 1984, 1980, 1976, 2003, 1994, 1964 and 1998.

The score time-series presents a small, not-statistical significant decreasing trend of the treerings width $\left(R^{2}=0.0026\right)$, which could be the result of the intense negative deviations (very narrow tree-rings) during the years 1999-2001.

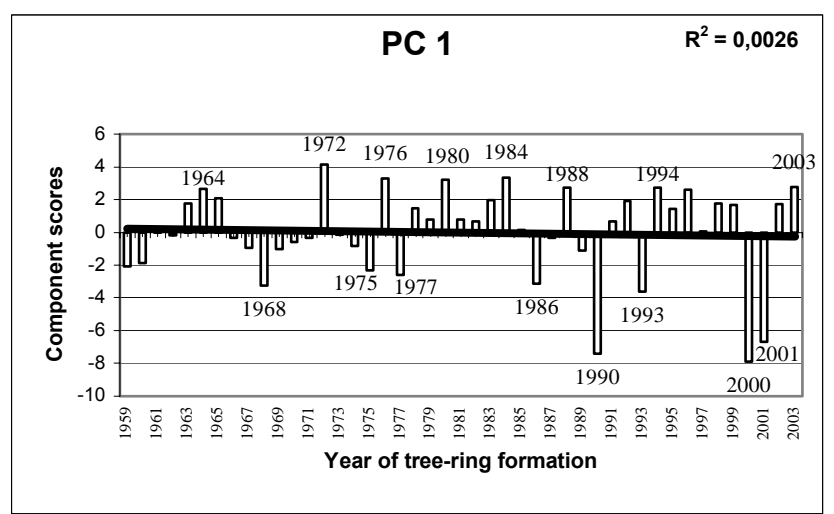

Figure 2: The PC1 scores for the 12 Aleppo pine populations derived from the application of the principal component analysis to the annual tree-ring indices. The trend line is also shown 


\subsection{Climatological analysis}

From the analysis of the PCA results on the residual values of precipitation, Tmax and Tmin, the first two principal components were retained due to the fact that they account for the largest percentage of the total variance (Table 4). The other PCs were not analyzed in the study since their percentage of variance is very small.

Table 4. Principal components derived from the 5 meteorological stations for precipitation (P), minimum (Tmin) and maximum (Tmax) temperatures

\begin{tabular}{crrrrrr}
\hline $\begin{array}{c}\text { Principal } \\
\text { component }\end{array}$ & \multicolumn{3}{c}{$\%$ total variance } & \multicolumn{3}{c}{$\begin{array}{c}\text { Cumulative \% variance } \\
\text { explained }\end{array}$} \\
& P & Tmin & Tmax & P & Tmin & Tmax \\
\hline PC1 & 82,6 & 88,2 & 88,5 & 82,6 & 88,2 & 88,5 \\
PC2 & 7,7 & 5,1 & 5,6 & 90,3 & 93,3 & 94,1 \\
PC3 & 4,5 & 2,9 & 2,2 & 94,8 & 96,2 & 96,3 \\
\hline
\end{tabular}

The results of the PCA application to each of the climatic parameters are the following:

Precipitation: The correlation coefficients between the monthly precipitations of the selected stations are very high and vary between 0.72 and 0.86 . The greatest values were observed between the stations of the National Observatory of Athens (NOA) and N. Philadelphia, as well as between Piraeus and Elliniko. On the other hand the smallest values were found between the station of Tatoi and the NOA and Elliniko. The first two principal components explain the $90.3 \%$ of the total variance of the residual values of the monthly rainfall. Especially the PC1, which accounts for the $82.6 \%$ of the variance, measures the common homogeneous variability of the monthly precipitation totals of the 5 stations. The PC2, with a percentage of $7.7 \%$, represents the gradients of precipitation from north to south, the direction to high the rainfall totals decrease (not shown).

Moreover, from the analysis of the annual variability of the monthly time-series of the scores, it was found that there are some years with significant deviations for the monthly mean (not shown). Suggestively, great positive deviation (precipitation increase) was observed mainly during winter and spring months of the hydrological years 2002-03, 1993-94, 1983-84 and 1971-72. Conversely, significant negative deviations (precipitation decrease) were observed during the winter and spring months of the hydrological years 2000-01, 1999-00, 1989-90 and 1976-77. From the computation of the linear trends of the monthly data, showed that the time-series do not present statistical significant trends during the study period $\left(R^{2}=0-0.05\right)$, (Figure 3). Similar results were derived from the study of Katsoulis and Kambetzidis (1989) on the annual precipitations of the National Observatory of Athens.

Mean minimum and maximum temperature: As in the case of precipitation, the correlations among the stations both for Tmin and Tmax are very high, and the correlation coefficients range from 0.76 to 0.90 and from 0.74 to 0.92 respectively. The greatest values were observed among the neighboring stations and the smallest ones between the station of Tatoi and stations remote from it. The first two PCs account for the $93.3 \%$ of the total variance of the mean minimum temperature and $94.1 \%$ of the mean maximum temperature. More specifically the PC1 which is associated to the $88.2 \%$ and $88.5 \%$ of the total variance of the Tmin and Tmax correspondingly, measures the common homogeneous variability of the temperature in the 5 stations under study. The second principal component (PC2) that explains the $5.1 \%$ (Tmin) and $5.6 \%$ (Tmax) of the total variance represents the increase of temperature with a gradient from north to south (not shown), where the altitude of the stations plays also an important role for this distribution.

On a next step, the monthly time-series of the scores of Tmin and Tmax were analyzed for the hydrological years $1958-59$ and 2002-03, but due to spate limitations the equivalent figures were not included in the study. From the analysis of the annual variability of the examined time-series it was found that there are some years that present significant deviations from the monthly average. High positive deviations (high temperatures) were observed mainly during the spring and summer months (i.e. the hydrological years 2000-01, 2001-02 and 1999-00). On the other hand, intense negative deviations (low temperatures) 
were observed generally during the winter months (hydrological years 1979-80, 1983-84 and 1963-64). The analysis also showed that the minimum temperatures do not present statistically significant trend $\left(R^{2}=0\right.$ to 0.08$)$, while for the maximum temperatures, the months of June $\left(R^{2}=0.556, P<0.05\right)$ and July $\left(R^{2}=0.452, P<0,05\right)$ presented statistically significant positive trends. Generally, this increasing trend is more intense during the period from May to August and it is more significant from the mean maximum temperatures than the minimum ones. This could be interpreted taking into account the thermal urban effect in the city of Athens (Philandras et al., 1999; Kabetzidis, 2005). Besides, generally in Greece, the mean maximum temperatures present more significant extreme values than the mean minimum temperatures (Xoplaki et al., 2003). It is also worth noticing that this increasing trend is more intense during the summer months of the last decade. According to Founda et al. (2004), the summers of 2001, 2000 and 1999 were the warmest ones ever recorded in the city of Athens for the time period from 1897 to 2001.

Relationships between the climate parameters and the tree-rings: The results from the correlations between the PCA scores of the tree-ring widths of the 12 Aleppo pine populations and the PCA scores of the monthly precipitation, maximum and minimum temperatures are presented in Figure 3. From their analysis yields that the tree-ring widths show a weak positive correlation with the winter precipitation that precedes the formation of the tree-ring. A positive correlation was also found with the March rainfall of the same year of the formation of the tree-ring. Conversely, negative are the correlations with the mean minimum and maximum temperatures of Mars and April (Figure 3).

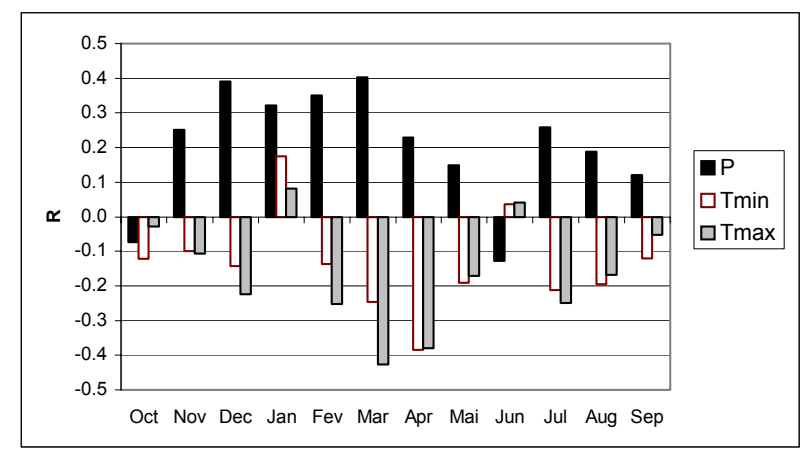

Figure 3. Correlation coefficients between principal component scores of tree-ring width and precipitation $(P)$, Tmin Kaı Tmax, per month, for the study period

Aiming at a more detailed analysis of the role of the climatic parameters to the formation of the tree-rings, the hydrological years with the most narrow and the widest rings were chosen in order to examine their precipitation and Tmax and Tmin principal component scores. The hydrological year 1999-00 (the most narrow tree-ring) presented a significant decrease of the winter, spring and summer rainfall totals, while it had high temperatures during the spring and summer period (Figure 4a). The decrease of precipitation before and during the growing period and the high spring and summer temperatures result to the formation of a narrow treering.

For the hydrological year 1971-72 (wide tree-ring of 1972), high precipitation totals and low maximum temperatures were found during the spring and summer months. This type of climate conditions favors the widening of the tree-rings (Figure $4 \mathrm{~b}$ ).
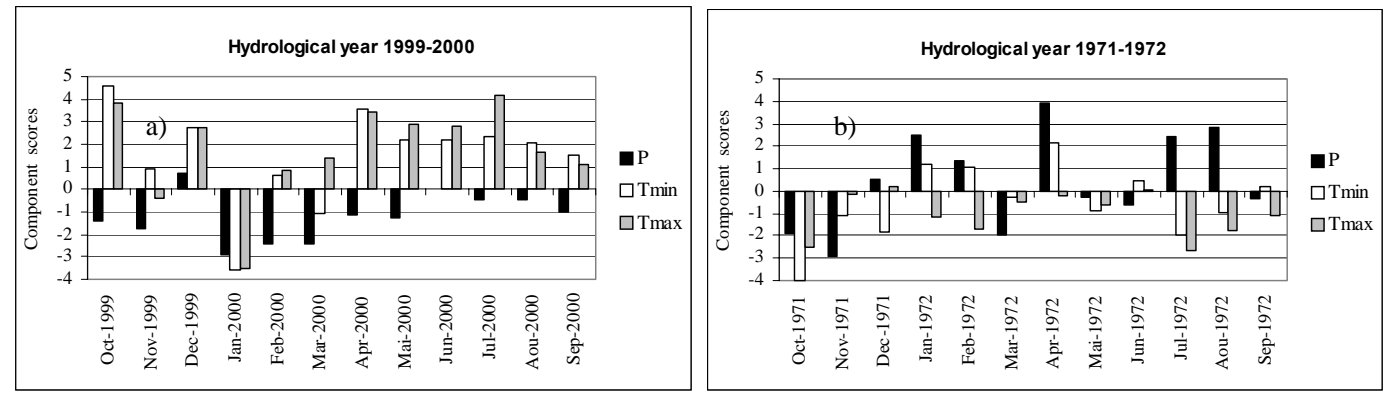

Figure 4. Precipitation Tmin kaı Tmax scores of PC1, per month, for the hydrological year 1999-2000 (a) and the hydrological year 1971-1972 (b) 
Generally, in Greece, the tree-ring width of Aleppo pine is positively correlated with the winter (Dec - Jan) and spring (April - May) precipitation, while negative correlations are noted with the spring temperatures (Papadopoulos et al., 2001).

\section{CONCLUSIONS AND DISCUSSION}

The Aleppo pine tree-rings widths in the Attica basin portray in a high percentage $(64 \%$ of the total variance), a homogeneous variability that could be interpreted as the common influence of the climate to the increase of the tree-rings widths. The percentage of this common variance could increase with the appropriate selection of the time-series of the trees that compose the mean time-series, as a consequence of minimization of the nonclimatic signal that these tree-rings present.

The variability of the climatic data is not so significant in order to explain a differentiation of the tree-ring trends during the study period (1959-2003). However, an increase of the extreme narrow tree-rings occurrence frequency could be observed, due to temperature increase and especially of the maximum temperatures during the spring and summer months. A small decrease of winter and summer rainfall might also have contributed to this direction (extreme narrow tree-rings).

Winter precipitation that precedes to the formation phase of the tree-rings as well as the spring rainfall totals that coincide to the beginning of the tree-ring growth, play a prevailing role to their development. On the other hand the high spring temperatures have the opposite result. The positive result of the winter precipitation could be attributed to the water storage into the soil for use during the growing period. Moreover, the spring precipitation could attribute to the increased water demands for the various physiological processes such as the intense cambium reactivation and growth release after winter dormancy. Regarding temperature, the inverse relationship observed during spring could be interpreted in connection with the positive relations with precipitation and the evapotranspiration process. Similar relationships were observed for Aleppo pine in other regions of Greece (Papadopoulos et al., 2001) as well as in other Mediterranean countries (Serre, 1976; Lev-Yadun et al., 1981; Safar, 1994). The wide tree-rings were observed in hydrological years that present high rainfall totals during winter and spring. Contrarily the narrow tree-rings were found in years that are characterized with an intense precipitation decrease and very high temperatures during the growing period (March - September) as well as a decrease of precipitation during the winter just before the growing period. Based on the above mentioned results, this climate effect on tree-ring width of Aleppo pine may be generalized for other areas of the species distribution in Greece.

The examination and the analysis of the relationships between the local climate parameters and the Aleppo pine tree-ring increase in the Attica basin could be the basis for a future more detailed and thorough statistical investigation of the climate-growth links. The present study could contribute to the dendroclimatological research as well as to the reconstruction of the climate parameters, which has been the subject of several studies during the last years in the eastern Mediterranean employing long tree-ring timeseries of the region (Hughes et al., 2001; Akkemik and Aras, 2005; Touchan et al., 2005). Such information on long-term records of tree growth under natural environmental conditions, could contribute to our knowledge of the possible impacts of climate change on forests dynamics and productivity.

\section{ACKNOWLEDGMENTS}

The present study was conducted under the framework of a research program titled: "Climate - environmental changes and sensitivity of the Aleppo pine annual tree-rings (Pinus halepensis Mill.) in the Attica basin» of the project «EPEAEK: Environment Archimedes: Support for the TEI Lamias Research groups», $75 \%$ funded by the E.U and $25 \%$ by the National Ministry of Education and Religion. 


\section{REFERENCES}

Akkemik U. and Aras A. (2005) Reconstruction (1689-1994 AD) of April-August precipitation in the southern part of Central Turkey, Int. J. Climatol., 25, 537-548.

Alexandersson H., (1986) A homogeneity test applied to precipitation data, J. Climatol., 6, 661675.

Barbero M., Loisel R., Quezel P., Richardson D. and Romane F. (1998) Pines of the Mediterranean basin. In: Ecology and biogeography of pinus, Richardson D. (eds), Cambridge Univ. press, Cambridge 153- 170.

Berger A.L., Guiot, J. Mathieu L. and Munaut A.V. (1979) Tree rings and climate in Marocco, Tree ring bull., 39, 61-75.

Bartzokas A. and Metaxas D.A. (1995) Factor analysis of some climatological elements in Athens, 1931-1992: covariability and climatic change, Theor. Appl. Climatol., 52, 195-205.

Cook E., Briffa K., Shiyatov S. and Mazepa V. (1989) Tree-ring standardization and growth-trend estimation. In: Methods of dendrochronology. Applications in the environmental sciences. Cook and Kairiukstis (eds), Kluwer Academic Pub., International Institute for Applied Systems Analysis, 104-123.

Critchfield H. (1983) General climatology. Fourth Edition. Prentice-Hall, Inc. New Jersey, 453 pp.

Founda D., Papadopoulos K.H., Petrakis M., Giannakopoulos C. and Good P. (2004) Analysis of mean, maximum, and minimum temperature in Athens from 1897 to 2001 with emphasis on the last decade: trends, warm events, and cold events, Global and Planetary change, 44, 27-38.

Fritts H.C. (1976) Tree-rings and climate. Academic Press, London, 567 pp.

Garfi G. (2000) Climatic signal in tree-rings of Quercus pubescens s.I. and Celtis australis L. in South-eastern Sisily, Dendrochronologia 18, 41-51.

Guiot J. (1986) Sur la détermination de régions climatiques quasi-homogènes, Revue de statistiques appliquées, XXXIV (2), 15-34.

Guiot J. (1990) Methods and programs of statistics for paleoclimatology and paleoecology. Quantification des changements climatiques: Méthodes et programmes, Monographie $\mathrm{N}^{\mathrm{O}} 1$. INSU, PNEDC, $253 \mathrm{pp}$.

Hughes M.K., Kuniholm P.I., Garfin G.M., Latini C. and Eischeid J. (2001) Aegean tree-ring signature years explained, Tree-Ring Research 57(1), 67-73.

Kaennel M. and Schweingruber F.H. (1995) Multilingual glossary of dendrochronology. Terms and definitions in English, German, French, Spanish, Italian, Portuguese, and Russian. WSL/ FNP, Haupt, pp. 467.

Kambetzidis H. (2005) The climate of Athens, Research and Technology - G.S.R.T., 8, 23-28.

Katsoulis B. and Kambetzidis H., (1989) Analysis of the long-term precipitation series at Athens, Greece, Clim. Change 14, 263-290.

Kutiel P., Kutiel H. and Lavee H. (2000) Vegetation response to possible scenarios of rainfall variations along a Mediterranean - extreme arid climatic transect, J. of Arid Environments, 44, 277-290.

Lev-Yadun S., Liphschitz N. and Waisel Y. (1981) Dendrochronological investigations in Israel: Pinus halepensis Mill. The oldest living pines in Israel, La Yaaran, 31 (1-4), 49-52 and 2-8.

Maheras P. (1981) La variabilité des précipitations dans la Mer Egée, Arch. Met. Geoph. Biokl., B 29, 157-166.

Maheras P. Xoplaki E. and Kutiel H. (1999) Wet and dry monthly anomalies across the Mediterranean basin and their relationship with circulation, 1860-1990, Theor. Appl. Climatol., 64, 189-199.

Mariolopoulos E.G. (1962) Fluctuation of rainfall in Attica during the years of the erection of the Parthenon, Geofisica Pura E Applicata, 51 (1), 243-250.

Mokrim A. (1989) Contribution a l'étude dendrochronologique du pin d'Alep (Pinus halepensis Mill. naturel et la variabilité pluviometrique au Maroc, Thèse Doc es sci., Inst. Agron. et Veter. Hassan II, Rabat, $175 \mathrm{p}$.

Nicault A. (1999) Analyse de l'influence du climat sur les variations inter et intraannuelles de la croissance radiale du pin d'Alep Pinus halepensis Mill. en Provence calcaire. Thèse Doc., Univ. Aix-Marseille III, 254p.

Papadopoulos A. (1993) Dendrochronologie du pin d'Alep en Grèce: contribution aux études climatologiques, Pub. de l'AIC, 6, 254-262.

Papadopoulos A. (1994) Analysis of spatial variability of rain-thermic and dendrochronological data of continental Greece, In: Proceedings from the $2^{\text {th }}$ Panhellenic Scientific Congress of Meteorology - Climatology and Atmosphere Physics, 145-156. (In Greek). 
Papadopoulos A.M., Serre-Bachet F. and Tessier L. (2001) Tree ring to climate relationships of Aleppo pine (Pinus halepensis Mill.) in Greece, Ecologia Mediterranea, 27 (1), 89-98.

Papadopoulos A, Pantera A., Goudelis G., Rarfogiannis Y., Stamatopoulos E., Vergos S. (2006) Sensitivity of tree rings of Allepo pine (Pinus halepensis Mill.) to climatic conditions for the period 1960-2003 at the basin of Attica In: Proceedings from the $12^{\text {th }}$ Panhellenic Forestry Congress, "Forest and water Forest environment protection", Hellenic Forestry Association ed., 379-386. (In Greek).

Philandras C.M., Metaxas D.A. and Nastos P.Th. (1999) Climate variability and urbanization in Athens, Theor. Appl. Climatol., 63, 65-72.

Quezel P. (1974) Les forêts du pourtour méditerranéen. UNESCO, Prog. homme et biosphère, 53 p.

Rathgeber C., Nicault A., Kaplan J.O. and Guiot J. (2003) Using a biogeochemistry model in simulating forest productivity responses to climatic change and $\left(\mathrm{CO}_{2}\right)$ increase: example of Pinus halepensis in Provence (south-east France), Ecological Modeling, 166, 239-255.

Régant Instruments (2001) Windendro 2001a. User Manual. Régent Instruments, Québec, 86pp.

Safar W. (1994) Contribution a l'étude dendroécologique du pin d'Alep (Pinus halepensis Mill.) dans une région semi-aride d'Algérie: L'Atlas Saharien (Ouled Nail - Aurès - Honda). Thèse Doc., Univ. Aix-Marseille III, 215p.

Schweingruber F.H. (1988) Tree Rings. Basic and applications of dendrochronology. Kluwer, Academic Publishers, Dordrecht, $276 \mathrm{pp}$.

Schweingruber F.H. (1996) Tree Rings and Environment. Dendroecology. Birmensdorf, Swiss Federal Insitute for Forest, Snow and Landscape Research. Haupt. pp. 609.

Serre F. (1976) Les rapport de la croissance et du climat chez le pin d'Alep (Pinus halepensis Mill.). 1. - Méthodes utilisées. L'activité cambiale et le climat, Oecol. Plant., 11 (2), 143-171.

Serre-Bachet F. (1985) La dendrochronologie dans le bassin méditerranéen, Dendochronologia, 3, 77-92.

Serre-Bachet F. (1992) Les enseignements écologiques de la variation de l'épaisseur du cerne chez le Pin d'Alep, Forêt medit., XIII(3), 171-176.

Touchan R. and Hughes M.K. (1999) Dendrochronology in Jordan, J. of Arid Environments, 42, 291-303.

Touchan R., Xoplaki E., Funkhouser G., Luterbacher J., Hughes K., Erkan N., Akkemik U. and Stephan J. (2005) Reconstruction of spring/summer precipitation for the eastern Mediterranean from tree-ring widths and its connection to large-scale atmospheric circulation, Clim. Dyn., 25(1), 75-98.

Xoplaki E., Luterbacher J., Patrikas, J. and Maheras P. (1998) Les précipitations hivernales en Grèce et leurs rélations avec la circulation atmospéhrique au niveau de $500 \mathrm{hPa}, \mathrm{Pub}$. de l'AIC, 11, 374-382.

Xoplaki E., Gonzalez-Rouko J.F., Gyalistras D., Luterbacher J., Rickli R. and Wanner H. (2003) Interannual summer air temperature variability over Greece and its connection to the largescale atmospheric circulation and Mediterranean SSTs 1950-1999, Clim. Dyn., 20, 537554. 